Article

\title{
Why Do Digital Native News Media Fail? An Investigation of Failure in the Early Start-Up Phase
}

\author{
Christopher Buschow \\ Department of Media Management, Faculty of Media, Bauhaus-Universität Weimar, 99423 Weimar, Germany; E-Mail: \\ christopher.buschow@uni-weimar.de
}

Submitted: 4 December 2019 | Accepted: 20 February 2020 | Published: 16 April 2020

\begin{abstract}
Digital native news media have great potential for improving journalism. Theoretically, they can be the sites where new products, novel revenue streams and alternative ways of organizing digital journalism are discovered, tested, and advanced. In practice, however, the situation appears to be more complicated. Besides the normal pressures facing new businesses, entrepreneurs in digital news are faced with specific challenges. Against the background of general and journalism specific entrepreneurship literature, and in light of a practice-theoretical approach, this qualitative case study research on 15 German digital native news media outlets empirically investigates what barriers curb their innovative capacity in the early start-up phase. In the new media organizations under study here, there are-among other problems-a high degree of homogeneity within founding teams, tensions between journalistic and economic practices, insufficient user orientation, as well as a tendency for organizations to be underfinanced. The patterns of failure investigated in this study can raise awareness, help news start-ups avoid common mistakes before actually entering the market, and help industry experts and investors to realistically estimate the potential of new ventures within the digital news industry.
\end{abstract}

\section{Keywords}

digital-born news media; digital native news media; entrepreneurial journalism; news start-ups; practice theories

\section{Issue}

This article is part of the issue "Digital Native News Media: Trends and Challenges" edited by Ramón Salaverría (University of Navarra, Spain).

(C) 2020 by the author; licensee Cogitatio (Lisbon, Portugal). This article is licensed under a Creative Commons Attribution 4.0 International License (CC BY).

\section{Introduction}

Entrepreneurship and novel business ventures are seen as crucial drivers of media industry change and transformation (e.g., Deuze \& Witschge, 2020; Küng, 2015; van Weezel, 2010). In theory, digital native news outlets such as BuzzFeed (US), Mediapart (France) or De Correspondent (Netherlands) can be environments where new products, alternative revenue streams, and innovative ways of organizing digital journalism are discovered, tested, and advanced. However, in practice, the situation seems to be more complicated. Regardless of the type of industry, most newly established ventures fail: In developed countries, only around half of them remain in business for at least five years (Shane, 2008, p. 98). Moreover, besides the usual pressures that cause start-ups to terminate business such as market compe- tition or poor product performance, previous research has shown that entrepreneurs in digital news face challenges such as lack of business knowledge, low social capital, entrenched legacy media thinking, and role conflicts (e.g., Heft \& Dogruel, 2019; Naldi \& Picard, 2012; Powers \& Zambrano, 2016; Salaverría, Sádaba, Breiner, \& Warner, 2019).

While some research has been carried out on their difficult market situation (e.g., Bruno \& Nielsen, 2012; Nicholls, Shabbir, \& Nielsen, 2016), there a particular research gap persists concerning the typical pitfalls of digital native news media in their early start-up phase during the period in which the conditions of the media market have not yet exerted much pressure on them. As in other industries (e.g., Loasby, 2007), it is assumed that many of these ventures never reach a company life-cycle stage where they can operate and potentially thrive in 
the market. Therefore, this article addresses the following research question:

RQ: Why do digital native news media fail in their early start-up phase?

To answer this question, 15 news start-ups in the German market were examined applying in-depth case study research. The article approaches its research topic from a practice-theoretical angle (e.g., Champenois, Lefebvre, \& Ronteau, 2019; Witschge \& Harbers, 2018): By closely focusing on actual patterns of entrepreneurial activity during the early start-up stage, a detailed and nuanced picture of the mutual processes surrounding the failure of digital native news media can be drawn, going beyond the often vague factors compiled in general entrepreneurship literature. The conclusions of this study can help news start-ups to survive the rough phase before actual market entry and help industry experts as well as investors to realistically estimate potential of these ventures.

\section{Theoretical Approaches}

\subsection{Potential of Digital Native News Media in the Transformation of Journalism}

In the last few years, globally, a large number of new journalistic organizations - often referred to as digital-born news media, digital native news media, news/journalism start-ups - have been started aside from traditional companies and institutionalized media markets (e.g., Arrese \& Kaufmann, 2016; Deuze \& Witschge, 2020; Sehl, 2019; Usher \& Kammer, 2019; Wu, 2016). Exemplarily ventures include outlets such as The Huffington Post in the US, El Diario in Spain, Krautreporter in Germany, or Zetland in Denmark. An established definition states that these outlets are built around a digital presence, have no formal affiliation to any legacy news organization, and seek to be recognized as journalistic by their peers (Bruno \& Nielsen, 2012; Deuze \& Witschge, 2020; Powers \& Zambrano, 2016).

In Germany, for instance, several of these ventures have been launched in the last couple of years, particularly following the economic and financial downturn of the late 2000s and the closure of newspapers such as the German edition of The Financial Times in 2012 (Buschow, 2018). Unlike in the US (e.g., Pew Research Center, 2019), no precise figures and longitudinal data are available. In sum, however, the crisis has affected the German media market to a lesser degree: Germany is still regarded as a newspaper country with a media landscape mainly populated by private legacy players and public broadcasters (Friedrichsen, 2017; Nicholls et al., 2016). This creates a complicated market situation for new entrants (if they even make it that far). Moreover, little private seed funding (e.g., venture capital) is available (Buschow, 2018) and despite the increasingly difficult situation of local journalism, state subsidies have only recently been discussed. In contrast to other European countries (e.g., van Kranenburg, 2017), so far, there are only a few small, regionally-orientated innovation funds for new media organizations available. Overall, the media market's relatively stable situation and the lack of seed funding reduces the probability of success for startups in German journalism.

Nevertheless, even in this situation digital native news media are perceived as laboratories for innovation and as trendsetters, offering hope for the future of journalism (Buschow, 2018). At least two streams of literature from media management research explain their innovative potential:

1. Unlike legacy media organizations, news start-ups are, in principle, far less dependent on extant sector-specific traditions and aim to differentiate themselves from other established market players. Above all, it seems important that they are born and "imprinted" (Stinchcombe, 1965, p. 153) under conditions of digital network media. This is what fundamentally distinguishes them from newspaper publishers who are often caught up in the structural logic of their main production technology-i.e., printing media-and the resulting production rhythms, work practices, business models, etc. (Koch, 2008). Therefore, from the perspective of the organizational path dependency approach (Sydow, Schreyögg, \& Koch, 2009), in contrast to traditional media houses, start-ups might be more likely to create novel products, alternative revenue streams, and organization models for journalism aside from the current industry pathways.

2. Neo-institutional analysis suggests that isomorphic tendencies between start-ups and legacy media will arise (Carroll \& Hannan, 2000; DiMaggio \& Powell, 1983). These convergences are driven by an increase in the number of actors who observe and imitate alternative structures, practices, and products as well as by the exchange of employees between these organizations. Hence, new institutionalism implies that novel ventures can act as role models and prototypes for the transformation of legacy media companies and the industry as a whole (Deuze, 2017; Wagemans, Witschge, \& Deuze, 2016).

In light of these theoretical arguments, new venture creation appears to be a promising engine of innovation and renewal in the media industry. In practice, however, the realization of this theoretical potential is limited by the problems and challenges faced by novel organizations in digital journalism.

\subsection{Causes of Failure: Why Do Start-Ups Terminate Business?}

In line with empirical success factor research within studies of business and management, research into gen- 
eral entrepreneurship is primarily concerned with factors that enhance the chances of a start-up's prosperity. However, this stream of literature cannot hide the fact that, regardless of the industry type, high start-up closure rates are observed: For instance, Schindele and Weyh (2011) were able to show that 50 percent of all businesses in a West German cohort started from 1976 to 2005 were shut down during their first six to seven years. Entrepreneurship research expects a general "liability of newness": The younger an organization, the higher the probability of its shutdown (Stinchcombe, 1965, p. 148). However, it should be noted that not all start-ups close through failure, but through their own profitable exit or voluntary discontinuation (Parker, 2009, pp. 386-388).

In general, companies go through several development stages along a defined life-cycle (e.g., Greiner, 1972), typically divided into pre-seed, seed, growth, establishment, and consolidation/revitalization. Van Gelderen, Thurik, and Bosma (2005, p. 366) further differentiate the early start-up phase (pre-seed and seed) into four stages: A first stage, where the intention to establish an enterprise is developed; a second, where the entrepreneurial opportunity is recognized and a concept is developed; a third, where resources are allocated and the organization is set-up; and a fourth, where the venture starts to operate on the market. The latter three stages, in particular, describe the crucial entrepreneurial process of moving from a simple business idea to the growth of a company.

However, in each of these life-cycle phases, a variety of individual, organizational, and structural reasons can lead to the termination of activities-implying that a company does not reach the next phase of the lifecycle. Regardless of the stage of development, a review of entrepreneurship literature shows that the following sources of failure are typically considered in research (e.g., Carroll \& Hannan, 2000; Neumann, 2017; Parker, 2009; Stinchcombe, 1965):

- Knowledge, i.e., lack of (business/industry) experience, education, entrepreneurial capabilities, managerial ability, technical skills;

- Team constellations, i.e., small number of founders, coordination difficulties, lack of competences;

- Resources, i.e., insufficient assets, lack of (seed) money, initial capital (liability of smallness);

- Networks, i.e., difficulties of establishing relationships with customers, suppliers, and business partners;

- Industry configuration, i.e., characteristics of markets, intensity of competition, lack of need for product(s);

- Legitimacy, i.e., lack of societal acceptance and reputation.

This summary of general failure factors sensitizes researchers to possible lines of inquiry. However, it seems almost impossible to compile a both comprehensive and adequately specified list of determinants spanning all industries. Moreover, previous research seldom distinguishes the patterns of failure which relate to a company's stage in its life-cycle (van Gelderen et al., 2005). Thus, a greater empirical value should lie in the close investigation of certain start-ups' specific challenges in order to obtain a detailed and differentiated understanding of the processes surrounding failure in one industry (Neumann, 2017).

As the media industry differs considerably from other industries (Lowe, 2016), there is reason to assume that patterns of failure are likewise distinct from start-ups' demise in other sectors. Indeed, previous research has stressed the following problem areas faced by news start-ups: lack of business and market knowledge due to founders' professional backgrounds in journalism (e.g., Salaverría et al., 2019); low social and symbolic capital held by journalist founders (Powers \& Zambrano, 2016); entrenched legacy media thinking applied to new ventures, which leads to outdated ideas about organizations, revenue models, users etc. (Naldi \& Picard, 2012; Sommer, 2018); as well as role conflicts that give rise to ethical challenges and organizational tensions (Carbasse, 2015; Heft \& Dogruel, 2019). However, although failure appears to be common in digital native news media, and even the survival of a newly started organization is often considered a success (e.g., Brouwers, 2018; Bruno \& Nielsen, 2012), the current state of research on this topic is still limited. So far, findings have tended to be merely auxiliary findings, having been gleaned from other studies which actually had different research interests.

Hence, in this literature review, two central limitations become apparent: First, the rather generalized factors which lead to failure, as identified by entrepreneurship studies, are too vague and are of only limited help in the sector-specific study of news start-ups. Second, although some research has been carried out on the (difficult) market conditions for digital native news media (e.g., Bruno \& Nielsen, 2012; Nicholls et al., 2016), the actual pitfalls and challenges in starting up such a venture are not well understood. In particular, the early start-up phase before media market conditions are able to exert much pressure has received little research attention so far. These limitations clearly underline the persistence of the research gap concerning the failure of digital native news outlets.

\subsection{Practice-Theoretical Perspective: Understanding Failure in Start-Up Practices of Digital-Born News Media}

In order to fill this gap and explore the failure of new ventures in the news industry in as nuanced a way as possible, this study applies a practice-theoretical perspective. Although a fragmented stream of literature with different schools of thought, theories of practice have attracted increasing attention in numerous fields of social sciences in recent years, since they potentially of- 
fer innovative ways of conceptualizing the social world (e.g., Nicolini, 2012; Reckwitz, 2002; Shove, Pantzar, \& Watson, 2012). This is also true for journalism studies (e.g., Witschge \& Harbers, 2018) and entrepreneurship research (e.g., Champenois et al., 2019; Johannisson, 2011). For instance, Champenois et al. (2019) recommended basically re-focusing entrepreneurship research "towards real entrepreneurial actions in which concrete people engage in particular times and in particular places or circumstances" (p. 6).

In this regard, theories of social practice are a particularly promising starting point for research in underexplored fields: While traditional entrepreneurship studies often tend to describe and explain starting up primarily based on the founders' intentions and characteristics or market determinants and, in doing so, overemphasize the role of either individual actors' capabilities or structural conditions, practice theories avoid such shortfalls (Champenois et al., 2019; Johannisson, 2011). A practice point of view helps to overcome the current lack of systematic understanding of new venture creation in the news industry by focusing on the concrete, situated activities in the ongoing processual becoming of an organization-on entrepreneurs' every-day steps in the creation of a new organization. The fundamental constituents of this process are considered to be social practices, typically understood as patterns of action that are regularly enacted in similar ways by different actors at different times and at different places/circumstances.

From this theoretical angle, starting a digital native news media organization is characterized by a set of interrelated start-up practices through which such organizations are developed and, if successful, perpetuated (Shove et al., 2012). In empirical research, start-up practices are not predefined by extant categories or definitions, rather they are uncovered from a "bottom-up" perspective in order to grasp the context-specific entrepreneurial activities, resources, procedures as well as the meaning attached to them in practice (Champenois et al., 2019). In this study, practice theories form "a heuristic device, a sensitising 'framework"' (Reckwitz, 2002 , p. 257) for the empirical exploration of activities as well as the failures in setting up a digital native news media-a process that has so far remained largely unexplored.

\section{Methods}

A practice-theoretical approach calls for an open and exploratory research design in order to reveal a broad range of specific sources of failure in start-up practices. Therefore, qualitative comparative case study research (Yin, 2014) was conducted, investigating 15 digital-born news media within the German market. Cases were included that met the definition in Section 2.1: Those ventures which started independently of legacy media organizations-no spin-offs or new business units of traditional publishers or broadcasters-as well as ventures primarily focused on the production of journalism, not its dissemination or distribution, and ventures that described themselves as journalistic and seek to be recognized as such by their peers.

\subsection{Sample}

Because of the volatility and opacity of the field under investigation, three complementary pre-studies (a standardized survey of 29 German media experts, a systematic analysis of trade media coverage as well as an investigation of investors, media industry congresses, and awards/prizes) were triangulated to identify a population of around 200 German news ventures. From this population, 15 cases were selected for in-depth research.

Case selection was based on a most-different design reflecting the following consideration: If the same entrepreneurial activities and challenges occur in a broad variety of disparate organizations, this should increase the generalizability of the empirical findings. The diversity of the cases was determined by the following three criteria, that were determined prior to the in-depth investigation: 1) company status (for profit vs. not-forprofit; identified by corporate form); 2) type of media product(s) produced (digital pure player vs. hybrid media products, e.g., both online and print publications); 3) audience scope (broad general coverage vs. specialized niche journalism).

All start-ups investigated were a maximum of four years old and in one of the following three early stages differentiated by van Gelderen et al. (2005): concept development, resource allocation, or first market operations. To reduce "survival bias" - a bias toward organizations that have succeeded (Parker, 2009, p. 8)-ventures that (at the time of investigation) either struggled with their business or had already been shut down were included as well. Even though this study focuses on failure, it was not only failed cases that were examined: This was to provide a retrospective view of the entire process of venture creation and to identify critical turning points in the history of companies. Due to the number of cases investigated, no longitudinal research framework could be applied. Despite their diversity, what these companies share is that, overall, they have a small workforce size (typically only founders and a network of supporters), achieve low audience reach and-even if they work for profit-do not generate a major surplus for their founders. Table 1 gives a more detailed overview of the cases examined in this study.

\subsection{Data Collection}

The 15 selected cases were examined in-depth, based on the triangulation of 22 qualitative, semi-structured interviews with founders (approx. 32 hours of audio material), 164 external and internal documents and, where possible, short site visits. 
Table 1. Cases investigated in empirical research.

\begin{tabular}{llllll}
\hline Case & Age & Company status & Type of media product(s) & Audience scope & Status at time of investigation \\
\hline 1 & 2 years & For profit & Hybrid & General & In operation \\
2 & Less than 1 year & Not-for-profit & Digital pure player & General & Struggling \\
3 & 1 year & For profit & Hybrid & General & In operation \\
4 & 2 years & For profit & Digital pure player & General & In operation \\
5 & 4 years & For profit & Digital pure player & General & In operation \\
6 & 1 year & For profit & Hybrid & Niche & In operation \\
7 & 2 years & For profit & Hybrid & General & Struggling \\
8 & 4 years & For profit & Digital pure player & Niche & Failed \\
9 & 2 years & For profit & Digital pure player & Niche & Struggling \\
10 & 4 years & Not-for-profit & Hybrid & General & In operation \\
11 & 2 years & For profit & Digital pure player & Niche & Failed \\
12 & 2 years & For profit & Hybrid & General & In operation \\
13 & 1 year & For profit & Hybrid & General & In operation \\
14 & 1 year & For profit & Digital pure player & General & Struggling \\
15 & 2 years & For profit & Hybrid & General & In operation \\
\hline
\end{tabular}

To address the research question, interviews were primarily aimed at a detailed reconstruction of the organization's early start-up phase with its every-day activities and events, decisions, as well as the barriers it faced. Documents used included internal (e.g., strategy papers, business plans) and external (e.g., interviews with founders in trade media, manifestos) texts by and about the organization, which had been produced without researcher's influence; they were included to gather further information from the company's past as well as indications of the intentions, goals, and objectives of the start-ups. Site visits focused on working procedures and organizational structures (by means of observable artefacts) and were recorded in the form of field notes.

Data collection took place in 2015 within a broader research project (Buschow, 2018). The case studies had to be anonymized to prevent any harm to the organizations involved, even if this reduces the research's reliability.

\subsection{Data Analysis}

All three data types obtained (interviews, documents, and field notes) were included in a qualitative content analysis (Mayring, 2000). Following up on practicetheoretical assumptions (e.g., Gherardi, 2019; Nicolini, 2012), the initial objective was to uncover start-up practices by analyzing the data bottom-up.

First, for each of the 15 cases, the nature of the organization's set up was derived from the data: What local activities were associated with starting an individual venture? Second, common activities were grouped across the entire sample of organizations with the aim to empirically show the typical ways of developing a new venture in German journalism. From this categorization procedure across cases, the following start-up practices emerged: Administrating, staffing/team building, networking/motivating, moderating, experimenting, and financing. To answer the research question, in a third step, for each of the six start-up practices, the pitfalls and challenges were reconstructed from the data: Where did founders stumble? Which specific barriers curbed the innovative capacities of these news start-ups?

\section{Findings and Discussion}

Why do news start-ups fail at an early stage of development? In what follows, context-specific and detailed patterns of failure are traced from the empirical case study research. Results are organized according to the six startup practices typically involved in the development of a news venture in Germany: Administrating, staffing/team building, networking/motivating, moderating, experimenting, and financing. The practice-theoretical angle forms the interpretative background of the following discussion, while the findings are also discussed against the backdrop of literature from entrepreneurship research and journalism studies.

\subsection{Administrating: Challenging Tasks and Unexpectedly High Workload}

All cases under investigation highlight that starting a new organization in German journalism requires far more extensive and diverse work than being a freelance journalist. In particular, administrative practices (e.g., accounting, negotiating contracts, technology administration), formerly undertaken by the management side of newspaper publishers, also become the founders' responsibility (cf. Salaverría et al., 2019). In contrast, founders who initially expected that 'doing entrepreneurship' would open up new freedom for their own journalistic workwriting, filming, producing, etc. - clearly underestimated the steps involved in setting up a new venture (e.g., cases 5, 9, 10, 11).

Around half of the cases investigated emerged as a result of criticism of legacy newspaper publishers, with 
which founders were dissatisfied (cases 1, 3, 5, 6, 9, $11,14,15)$. Many accused newspapers of hindering real journalistic work: "The journalism of legacy newspaper publishers is exactly that kind of journalism I do not want to do anymore. If there was only this journalism left, I would leave the profession" (case 15). Against this background, it is particularly noteworthy that the founders of case 11-after only a short period in their entrepreneurial role-clearly regretted that the support from publishers was now no longer available to them: "Please give us exactly these publishing staff [we always criticized as a barrier in legacy publishers]! Now we learned what newspaper publishers do for us and how they give us journalists the support [in terms of administration] we need" (case 11). Many of these nonjournalistic tasks are necessary even if fast growth, huge profits or a lucrative 'exit' from the company are not the main objectives of their founders, for instance, because they work on a not-for-profit basis.

The cases underline that news entrepreneurs in Germany are often (former) journalists (cases 2, 3, 7, 9, $11,12,15)$ who now operate beyond the scope of their previous activities and have not yet developed "standard social routines" (Stinchcombe, 1965, p. 149) for their new roles. This is also because new ventures can emerge rather spontaneously: Practice theories help to understand the study's empirical finding that some founders 'stumble' into their role (e.g., cases $12,13,15$ ). It is only through what they do, based on the start-up practices they adopt, that they become recognized and described as news entrepreneurs by others. For instance, the initiators of case 12 suddenly found themselves in the entrepreneurs' role, even though they had never intended this; trade media reported on them, they were regarded as role models and invited as speakers to news start-up conferences. Interpreted against practice theories, founders are actually made in their roles by the startup practices they adopt (Shove et al., 2012)-and, as the cases from the study show, there is a lot of potential for failure due to the challenging (administrative) tasks and unexpectedly high workload.

\subsection{Staffing: Teams Are too Homogeneous}

Concerning staffing, the teams behind German digital native news media are remarkably homogeneous. Founders rarely come from industries or professions other than journalism. Only two ventures in the diverse sample were started solely by outsiders: Case 8 by founders from culture and philosophy, case 14 by founders with backgrounds in general management, design, and technology. As mentioned above, many of the entrepreneurs in the sample had had traditional industry careers (cases 2, 3, 7, 9, 11, 12, 15): journalism schools, traineeships, and editorial jobs at newspapers or broadcasters.

When teams are formed around personalities with similar backgrounds, the diversity of emerging chal- lenges to starting up cannot always be efficiently addressed by the founders. It may be-as in some of the cases $(7,9,11,12)$-that there are no competent actors in the team to accomplish certain practices (e.g., activities in technology development, or sales). As a result, work often has to be outsourced (see Section 4.3) or these practices are completely neglected, possibly delaying or even suppressing the development of new ventures. Against this background, homogeneity of teams can thus be a decisive source of failure.

In contrast, if staffing brings together founders with complementary expertise, the diverse practices in news ventures can be undertaken with greater skill and flexibly. Founders with business backgrounds can help to tackle administrative practices involved in setting up new media companies (see Section 4.1). Coders and developers can help keep pace with the newest technological developments. One founder interviewed in the study underlines the need to include outsiders: "I do not really need any journalists. I do not want to do [business] with journalists" (case 15).

When outsiders are part of a team, this can also help to adopt mindsets and practices from other industries and professions, which may lead to new ways of thinking in journalism. As research on organizational formation has shown (e.g., Padgett \& Powell, 2012), innovation is most likely to be generated where people with multiple professional backgrounds collaborate.

\subsection{Networking: Lack of Contacts and Relationships}

Even if complementary skills are combined in a team, founders can hardly be expected to solve all entrepreneurial challenges on their own. From the very beginning, they need support to help them through the early start-up phase. However, in most cases, these supporters cannot be employed permanently. Thus, news ventures in Germany are heavily dependent on freelancers. Such assistance from the outside is needed in journalistic work but also in design, technology development, marketing, product, legal and accounting-in some cases unpaid as Table 2 highlights.

Empirical evidence from the cases highlights the development of relationships beyond the borders of the organization-i.e., networking - to be a core practice of founders in the early start-up phase. Since work is often unpaid, a key issue for founders is to motivate these supporters in the absence of financial incentives. Case 1 expresses this as follows: "In journalism, where so much is accomplished through social capital, it is hard to say that it does not matter which parties you go to." This result corresponds to research by Powers and Zambrano (2016) who can show that social and symbolic capital are crucial resources for new venture creation in the news industry.

In sum, the news start-ups under study here differ from extant publishing houses in that they have a postindustrial form of organization in which several tasks are outsourced to a network of partners. During the planned 
Table 2. Partners involved and type of integration.

\begin{tabular}{lll}
\hline Partners (Individual/corporate) & Type of integration & Cases \\
\hline Authors and supporters in journalism & Paid & $3,4,5,6,11,14,15$ \\
& Unpaid & $1,5,1,10,12,13,14$ \\
Designers (graphic design, editorial design, user experience reviews) & Paid & $4,6,14,15$ \\
& Unpaid & $1,2,3,10,11,12,13$ \\
Developers, coders (including web development), data experts & Paid & $1,6,7,10,11,14$ \\
& Unpaid & $9,11,12,13$ \\
Marketing, branding, sales consultants & Paid & - \\
& Unpaid & $1,2,3,12$ \\
Strategy, business/start-up consultants, project/product managers & Paid & 11 \\
Legal advisers and lawyers & Unpaid & $3,7,9$ \\
Accountants & Paid & 4 \\
& Unpaid & $2,3,4,7,11,13$ \\
\hline
\end{tabular}

site visits this became particularly clear: most of the organizations could not be investigated in person (cases 1, 2, $7-10,12,13,15)$ because they did not have permanent offices, but mainly worked with their supporters virtually through digital media tools. Conversely, if social capital is missing, a news start-up is hard to maintain and establish in Germany. A lack of networking, thus, is an important source of failure.

\subsection{Moderating: Conflicts between Journalistic and Economic Practices}

One consequence of the diverse everyday entrepreneurial activities in news ventures is a conflict between journalistic and economic perspectives. Typically, in digital-born news media there is a clash of certain start-up practices: Since founders have to be involved all over the place, traditionally competing and contradictory tasks of media work are taken on simultaneously by a single person.

As soon as the editor-in-chief of a venture-as in case 10-sells advertising space in parallel to writing stories, those in charge find themselves in a paradoxical dual role conducting editorial as well as economic practices (cf. Heft \& Dogruel, 2019). The potential conflicts of interests become more acute in those ventures where there is no physical division between departments in separated offices since work is mostly organized virtually (cases 1,2 , $7-10,12,13,15)$. Therefore, in start-ups, it is particularly difficult to achieve the news media's traditional separation between "church and state" (Carbasse, 2015, p. 267).

The cases illustrate that founders do reflect on such role conflicts; however, with increasing financial pressure it becomes difficult to remain true to one's own standards. For instance, in case 11 the team was forced to choose between "accepting a large corporate publishing project [something the founders had always refused to do] or running into personal bankruptcy." Subsequently, if no attempt is made to moderate these conflicts, some ventures cannot proceed due to contradictory and antagonistic practices during the start-up process. This potential source of failure clearly distinguishes digital-born news media from start-ups in other industries, where such conflicting objectives either do not arise or do so much less frequently.

\subsection{Experimenting: Ignoring the User's Perspective When Starting Up}

In contrast to research by Sommer (2018) who found high market and user orientation among (later stage) news start-ups, the digital native media examined in this study are often initiated from a media creators' perspective that seeks to replicate certain professional standards of journalism under conditions of digital media (cases 1 , $2,3,7-9,11,12,13,15)$. Founders first focus on the production of high-quality content rather than on profit and growth (cf. Deuze, 2017). However, this leads them to largely conceptualize their venture from a journalistic viewpoint. Thus, the interests and needs of potential users play only a minor role in their experimentation with news media content and new journalistic products.

This is aptly illuminated by case 9: Founders of this venture initially pursued two journalistic business ideas and finally chose the one that promised greater market potential-however, the market potential was not seen in terms of users, but in terms of journalistic talent and input. This meant that it was easier for the founders to retrieve existing content from fellow journalists and their networks: "That was the reason why we started [case 9]: Because we immediately had a few authors and knew there were good pictures, good stories" (case 9). Case 9 
also illustrates that the success of a venture is deliberately delayed because of journalistic principles:

Many journalistic products today write according to what people want to read....We could [also] do that, which would probably help us to create a certain reach more quickly....But I don't want to limit myself, I don't feel like doing this.... [What we want is to] open new doors for the reader that they may not have thought of. (case 9)

The fact that journalists often 'disregard' their readers is a well-known, historical finding of journalism research (e.g., Beam, 1995), even though increasing datafication and software-based audience observation have let to altered editorial practices in recent years (Tandoc, 2019). Under volatile conditions of the digital market, ignoring the user's perspective has become even more problematic. One of the news entrepreneurs sums up his observation from the failure of his venture as follows: "You cannot pass by the reader these days....This will rarely work immediately or if it does, then only for a short period. Therefore, always try to stay in touch [with your users]" (case 11).

The finding points to the fact that history also 'matters' in digital native news media. These organizations do not emerge out of nowhere, but-as seen through the lens of practice theories-are always shaped by the prior practices of their founders (Nicolini, 2012). Since many of them had had an earlier career in legacy journalism organizations (see Section 4.2), it is not surprising that longstanding practices and mindsets were transferred into new ventures. As a result of such "formational myopia" (Naldi \& Picard, 2012, pp. 76-77), digital native news media can be subject to an organizational path dependency as well (Sydow et al., 2009)-which is a decisive source of failure as these organizations then apply the same (unsuccessful) methods as legacy publishers do to respond to market challenges. One of the founders of case 14, an industry outsider, sums it up as follows:

Start-up founders in news industry...tend to disregard the business model. They [want] to revitalize the old business model. I think this is a great pity. We notice that the old model...is simply being continued.... have never seen such a thing in any other industry before. (case 14)

\subsection{Financing: (Under-)Financing News Start-Ups}

Today, starting up in the news industry is very cheap, to begin with. Similar to the findings by Compaine and Hoag (2012), German news ventures report only very few factors that hinder initial market access, as barriers to entry (e.g., costs of technology) haven fallen sharply with the rise of digital media. "You do not need much. All you need is a computer, an Internet connection, and a Wordpress system," states the founder of case 5 .
However, lowered barriers to initiating a media product in the digital market can lead to misconceptions and false incentives. The financing practices under study here highlight that German news ventures clearly underestimate the cost drivers of later day-to-day business: the difficulty in acquiring users and paying customers; communication via an increasing number of new social media platforms; and, above all, the labor-intensive production of high-quality content. For instance, the French digital native Mediapart, which was launched in 2007 by former Le Monde and Libération journalists (Wagemans et al., 2016), required almost six million Euro in its initial phase. The founders had made serious miscalculations, several times they had to attract further investors (Alfon, 2017). This study also documents cases with very low financial capital: For instance, the founder of case 1 started her business with around 1,000 Euro that she earned by selling 20 bottles of wine that her grandmother had given her at birth.

This is why news start-ups in the German market are often underfunded. Subsequently, atypical working relationships arise in some places (e.g., see Table 2): Key practices end up performed by employees who are engaged on temporary, sometimes voluntary, case-by-case basis. This dependency on unpaid work can contribute to a somehow paradoxical phenomenon: While digital-born news media are often motivated by critique of traditional publishers (see Section 4.1) and try to counteract their precarization of journalism (Örnebring \& Conill, 2016), they actually continue the familiar cost-saving tendencies of legacy news publishers and-as an unintended effect (Giddens, 1984)-thus even perpetuate this precarization. Against this background, misjudgments about the financial needs of digital native media organizations must be considered as a major source of failure.

\section{Conclusions, Limitations, and Future Research}

This article, by taking a practice-theoretical standpoint, has reconstructed the typical challenges and pitfalls in accomplishing start-up practices in the news industry. Beyond the rather vague categorizations of general entrepreneurship studies (cf. Section 2.2), the empirical bottom-up research conducted here contributes significantly to a context-specific understanding and interpretation of the failure of digital native news ventures in their early start-up phase.

Notwithstanding market conditions and structural contexts that obviously play a central role in failure within later development stages, this study focused on the pre-market phase in order to identify those barriers within start-up practices that can hinder the launch of a business in its initial phase even before media market factors exert any pressure. The cases studied shed light on typical start-up practices and key failures associated with them which need to be tackled before actually entering the market and creating media products: 
1. Founders need to develop a realistic picture of the administrative practices and the exact workload involved in starting up: They need to know what they are actually getting involved in;

2. It needs honesty that founders will not be able to handle everything on their own: Staffing and team building should be focused on bringing complementary skillsets together to carry out start-up practices more effectively;

3. In every field where teams lack expertise, founders need to rely on networking-i.e., their social capital-in order to motivate support to help them through the early start-up phase;

4. Founders must anticipate the potential (ethical) conflict between journalism and economics and develop ad hoc procedures to moderate this conflict during day-to-day business;

5. Such conflict can relate to user and market orientation: Even if such an orientation seems inevitable when experimenting with digital media products, it must not lead to journalistic standards being undermined;

6. Founders should be highly aware of the financial expenses that a news start-up requires: In their financing efforts, they should not fall for the false incentives that lowered market entry barriers have created.

If digital-born news media are to realize their theoretical potential as engines of innovation and renewal in the media industry (cf. Section 2.1), they must survive and prosper. However, in general, founders tend to be overoptimistic and rate the probability of failure as unrealistic (Parker, 2009, pp. 124-128). It is likely that news entrepreneurs also misjudge the challenges they will face when establishing new media ventures. Moreover, for founders who were previously journalists, setbacks are still conceptualized as a major problem, something to be avoided rather than a tool to learn from, as Brouwers (2018) points out. In general entrepreneurship literature, it is argued that first one generation of new ventures has to fail so that others can learn and thrive (e.g., Parker, 2009). News start-ups launched today are attempting to gain knowledge from the past failures of their predecessors in order to pre-empt and avoid the risks. Findings from this study can help nascent entrepreneurs in these efforts as well as emphasize the importance of failure for the overall news market.

Since this study examined the patterns of failure in the early start-up phase when new ventures are not yet exposed to the (competitive) circumstances of a specific (national) media market, the results from the particular German context should be of interest for, and largely be transferable to, other parts of the world. However, there are certainly differences between countries that comparative future research on news start-ups should consider (cf. Section 2.1): For instance, the amount of public and private seed funding (e.g., Kosterich \& Weber, 2019), which is insufficient for news start-ups in Germany, as well as the characteristics of founders (e.g., their willingness to take risks), which differ between geographical and cultural regions (Buschow \& Laugemann, 2020).

This article has limitations that open up avenues for future research: Although sampling was based on a maximum variation approach and thus covered a wide variety of news start-ups in the field, this study only investigated the German market. On this basis, research could be extended to more markets and regions and compare patterns of failure between them (e.g., Powers \& Zambrano, 2016). In addition, research should be expanded to include the factors that contribute to the failure of later life-cycle stages such as market pressure, product characteristics, growth crisis, etc. Furthermore, to better understand the complex processes of a news start-up's demise, future studies should draw on research designs that collect data at several points in time over a certain period of the company life-cycle; the present study has not applied a longitudinal design. In this context, ethnographic research approaches could prove useful. Such follow-up research would further deepen our understanding of the causes and processes surrounding failure, help develop measures to tackle them, and eventually help digital native news media to prosper.

\section{Acknowledgments}

I would like to acknowledge the three reviewers as well as Laurenz Schreiner who all significantly contributed to the further development of this article.

\section{Conflict of Interests}

The author declares no conflict of interests.

\section{References}

Alfon, D. (2017). Mediapart: A viable model? Chicago, IL: Stigler Center. Retrieved from https://research. chicagobooth.edu/ /media/3F4732395D95446981E C784F9C381CC1.pdf

Arrese, Á., \& Kaufmann, J. (2016). Legacy and native news brands online: Do they show different news consumption patterns? International Journal on Media Management, 18(2), 75-97.

Beam, R. A. (1995). How newspapers use readership research. Newspaper Research Journal, 16(2), 28-36.

Brouwers, A. D. (2018). Failure and understanding-with in entrepreneurial journalism. Journal of Media Business Studies, 14(3), 217-233.

Bruno, N., \& Nielsen, R. K. (2012). Survival is success journalistic: Online start-ups in Western Europe. Oxford: Reuters Institute for the Study of Journalism. Retrieved from https://reutersinstitute.politics. ox.ac.uk/our-research/survival-success

Buschow, C. (2018). Die Neuordnung des Journalismus: Eine Studie zur Gründung neuer Medienorganisatio- 
nen [Re-organizing journalism: A study on the formation of new media organizations]. Wiesbaden: Springer VS.

Buschow, C., \& Laugemann, R. (2020). What makes a media entrepreneur? Factors influencing entrepreneurial intention of mass communication students. Journalism \& Mass Communication Educator. Advanced Online Publication. https://doi.org/ $10.1177 / 1077695820912146$

Carbasse, R. (2015). Doing good business and quality journalism? Entrepreneurial journalism and the debates on the future of news media. Brazilian Journalism Research, 1(1), 256-277.

Carroll, G. R., \& Hannan, M. (2000). The demography of corporations and industries. Princeton, NJ: Princeton University Press.

Champenois, C., Lefebvre, V., \& Ronteau, S. (2019). Entrepreneurship as practice: Systematic literature review of a nascent field. Entrepreneurship \& Regional Development, 32(3/4), 281-312. https://doi.org/ 10.1080/08985626.2019.1641975

Compaine, B., \& Hoag, A. (2012). Factors supporting and hindering new entry in media markets: A study of media entrepreneurs. The International Journal on Media Management, 14(1), 27-49.

Deuze, M. (2017). Considering a possible future for digital journalism. Revista Mediterránea de Comunicación, 8(1), 9-18.

Deuze, M., \& Witschge, T. (2020). Beyond journalism. Cambridge: Polity.

DiMaggio, P. J., \& Powell, W. W. (1983). The iron cage revisited: Institutional isomorphism and collective rationality in organizational fields. American Sociological Review, 48(2), 147-160.

Friedrichsen, M. (2017). Market structure and innovation policies in Germany. In H. van Kranenburg (Ed.), Innovation policies in the European news media industry (pp. 85-96). Cham: Springer.

Gherardi, S. (2019). How to conduct a practice-based study: Problems and methods. Cheltenham: Edward Elgar.

Giddens, A. (1984). The constitution of society: Outline of the theory of structuration. Berkeley, CA: University of California Press.

Greiner, L. E. (1972). Evolution and revolution as organizations grow. Harvard Business Review, 50(4), 37-46.

Heft, A., \& Dogruel, L. (2019). Searching for autonomy in digital news entrepreneurism projects. Digital Journalism, 7(5), 678-697. https://doi.org/10.1080/ 21670811.2019.1581070

Johannisson, B. (2011). Towards a practice theory of entrepreneuring. Small Business Economics, 36(2), 135-150.

Koch, J. (2008). Strategic paths and media management: A path dependency analysis of the German newspaper branch of high quality journalism. Schmalenbach Business Review, 60(1), 50-73.

Kosterich, A., \& Weber, M. (2019). Starting up the news:
The impact of venture capital on the digital news media ecosystem. International Journal on Media Management, 20(4), 239-262.

Küng, L. (2015). Innovators in digital news. London: I.B. Tauris.

Loasby, B. J. (2007). A cognitive perspective on entrepreneurship and the firm. Journal of Management Studies, 44(7), 1078-1106.

Lowe, G. F. (2016). Introduction: What's so special about media management? In G. F. Lowe \& C. Brown (Eds.), Managing media firms and industries (pp. 1-20). Cham: Springer.

Mayring, P. (2000). Qualitative content analysis. Forum Qualitative Social Research, 1(2). Retrieved from http://www.qualitative-research.net/index.php/ fqs/article/view/1089/2385

Naldi, L., \& Picard, R. G. (2012). "Let's start an online news site." Opportunities, resources, strategy, and formational myopia in startups. Journal of Media Business Studies, 9(4), 69-97.

Neumann, M. (2017). Wie Start-ups scheitern: Theoretische Hintergründe und Fallstudien innovativer Unternehmen [How start-ups fail: Theoretical backgrounds and case studies of innovative companies]. Wiesbaden: Springer Gabler.

Nicholls, T., Shabbir, N., \& Nielsen, R. K. (2016). Digital-born news media in Europe. Oxford: Reuters Institute for the Study of Journalism. Retrieved from https://reutersinstitute.politics.ox.ac.uk/ourresearch/digital-born-news-media-europe

Nicolini, D. (2012). Practice theory, work, and organization: An introduction. Oxford: Oxford University Press.

Örnebring, H., \& Conill, R. F. (2016). Outsourcing newswork. In T. Witschge, C. W. Anderson, D. Domingo, \& A. Hermida (Eds.), The Sage handbook of digital journalism (pp. 207-221). Los Angeles, CA: SAGE.

Padgett, J. F., \& Powell, W. W. (Eds.). (2012). The emergence of organizations and markets. Princeton, NJ: Princeton University Press.

Parker, S. (2009). The economics of entrepreneurship. Cambridge, MA: Cambridge University Press.

Pew Research Center. (2019). State of the news media. Pew Research Center. Retrieved from https://www. pewresearch.org/topics/state-of-the-news-media

Powers, M., \& Zambrano, S. V. (2016). Explaining the formation of online news startups in France and the United States: A field analysis. Journal of Communication, 66(5), 857-877.

Reckwitz, A. (2002). Toward a theory of social practices: A development in culturalist theorizing. European Journal of Social Theory, 5(2), 243-263.

Salaverría, R., Sádaba, C., Breiner, J. G., \& Warner, J. C. (2019). A brave new digital journalism in Latin America. In M. Túñez-López, V. A. Martínez-Fernández, X. López-García, X. Rúas-Araújo, \& F. Campos-Freire (Eds.), Communication: Innovation \& quality. Studies in systems, decision and control (pp. 229-247). Cham: Springer. 
Schindele, Y., \& Weyh, A. (2011). The direct employment effects of new businesses in Germany revisited: An empirical investigation for 1976-2004. Small Business Economics, 36(3), 353-363.

Sehl, A. (2019). Digital news start-ups. In T. P. Vos \& F. Hanusch (Eds.), ICA international encyclopedia of journalism studies. Hoboken, NJ: Wiley Blackwell. Retrieved from https://doi.org/10.1002/ 9781118841570.iejs0075

Shane, S. A. (2008). The illusions of entrepreneurship. New Haven, CT: Yale University Press.

Shove, E., Pantzar, M., \& Watson, M. (2012). The dynamics of social practice. Everyday life and how it changes. London: SAGE.

Sommer, C. (2018). Market orientation of news startups. The Journal of Media Innovations, 4(2), 34-54.

Stinchcombe, A. L. (1965). Social structure and organizations. In J. G. March (Ed.), Handbook of organizations (pp. 142-193). Chicago, IL: Rand McNally.

Sydow, J., Schreyögg, G., \& Koch, J. (2009). Organizational path dependence: Opening the black box. Academy of Management Review, 34(4), 689-709.

Tandoc, E. C. (2019). Analyzing analytics. New York, NY: Taylor \& Francis.

Usher, N., \& Kammer, A. (2019). News startups. In H. Örnebring (Ed.), Oxford encyclopedia of journalism studies. Oxford: Oxford University Press. https://doi. org/10.1093/acrefore/9780190228613.013.827

van Gelderen, M., Thurik, R., \& Bosma, N. (2005). Success and risk factors in the pre-startup phase. Small Business Economics, 24(4), 365-380.

van Kranenburg, H. (2017). Summary and best practices. In H. van Kranenburg (Ed.), Innovation policies in the European news media industry (pp. 227-238). Cham: Springer.

van Weezel, A. (2010). Creative destruction: Why not researching entrepreneurial media? International Journal on Media Management, 12(1), 47-49.

Wagemans, A., Witschge, T., \& Deuze, M. (2016). Ideology as resource in entrepreneurial journalism: The French online news startup Mediapart. Journalism Practice, 10(2), 160-177.

Witschge, T., \& Harbers, F. (2018). Journalism as practice. In T. P. Vos (Ed.), Journalism (pp. 105-124). Berlin: De Gruyter.

Wu, L. (2016). Did you get the buzz? Are digital native media becoming mainstream? ISOJ Journal, 6(1), 131-149. Retrieved from https://isojjournal. wordpress.com/2016/04/14/did-you-get-the-buzzare-digital-native-media-becoming-mainstream

Yin, R. K. (2014). Case study research: Design and methods (5th ed.). Thousand Oaks, CA: SAGE.

\section{About the Author}

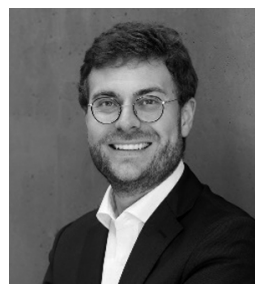

Christopher Buschow is an Assistant Professor in the Department of Media Management, Faculty of Media, at the Bauhaus-Universität Weimar, Germany. His research and teaching focus on start-ups and entrepreneurship in the media industry. Current research interests include digital news ventures, new organizational forms of journalistic work, as well as the willingness to pay for digital journalism. He has published widely in academic journals, edited books, and conferences. 